\title{
Generic Skills of Prospective Graduates from the Employers' Perspectives
}

\author{
Sivapalan Selvadurai ${ }^{1}$, Er Ah Choy $^{1} \&$ Marlyna Maros $^{1}$ \\ ${ }^{1}$ Faculty of Social Sciences and Humanities, Universiti Kebangsaan Malaysia, Bangi, Malaysia \\ Correspondence: Er Ah Choy, Faculty of Social Sciences and Humanities, Universiti Kebangsaan Malaysia, \\ 43600 Bangi, Selangor Darul Ehsan, Malaysia. Tel: 60-3-8921-3945. E-mail: erahchoy@yahoo.com
}

Received: May 12, 2012 Accepted: July 6, 2012 Online Published: September 27, 2012

doi:10.5539/ass.v8n12p295 URL: http://dx.doi.org/10.5539/ass.v8n12p295

\begin{abstract}
Past studies on employability of graduates have placed great emphasis on the supply side efforts in generic skills development which includes the tertiary curriculum design and delivery mechanisms. However, the responsibility of employers in providing training to prospective graduates and collaborating with universities in enhancing generic skills has been raised. On the demand side, there are numerous studies that have examined employer's perspective in the private sector but few studies have examined employer's perspective in the public sector. The objectives in this study are twofold: (1) to identify employers' perception of the ideal generic skills that graduate employees should possess, and (2) to elicit employers' perception of the lack of generic skills that prospective graduates (i.e.-industrial trainees) currently possess. A qualitative research design was utilized, involving primary interview data collected through 16 key informant interviews of employers in the public sector in Kuantan and Johor Bahru. These key informant employers were selected from the UKM's social science industrial trainees who attended training at these two sites. These interview data were analyzed using content analysis. The findings indicate that there are specific generic skills in the area of information and social interaction skills that the public sector employers seek from the graduates. This study implies the need for a stakeholder-responsibility approach in prescribing a comprehensive normative solution to the employability of graduates. In addition, it also postulates that the culture of learning and gaining varied skills in different spheres of life need to be inculcated amongst students from early years.
\end{abstract}

Keywords: employability, generic skills, prospective graduates, stakeholders

\section{Introduction}

The purpose of contemporary tertiary education is to ensure students learn and gain comprehensive quality and rounded education that makes graduates employable in a sustainable manner. This suggests that students not only "know" what they have learnt but also are able to "do" what they have experienced in the education process. Here the challenge is to ensure a tertiary level education that can prepare students who not only know theoretical knowledge, but also are able to practice it. In this connection, not only hard skills are necessary, but soft skills or generic skills are also equally needed to ensure employability of university graduates. Hard skills are technical or administrative procedures that are related to an organization's core business (Rao, 2010). In contrast, soft skills or generic skills are behavioural skills characterized by intangible attributes and entail emotional intelligence; and its subjective nature is hard to measure and very much relational in nature. In fact, some have referred to these generic skills as a set of achievements, understandings, and personal attributes that enables prospective graduates more likely to gain employment and be successful in their chosen field or career (Learning and Teaching Support Network, 2004). McQuaid et al. (2005, p. 191) view generic skills as contested and has been used as both a predominantly labour supply and a labour demand concept. They propose that the supply-side (i.e., education system) emphasizes instilling sets of skills that can contribute to improving individual employability. However, the demand-side (employer or industrial system) emphasis is on other contextual factors that are fundamental to those graduates gaining or changing employment (McQuaid et al., 2005, p. 194).

According to Rao (2010, p. 8) generic skills build self-esteem and self-confidence at the personal front that enable personal and professional advancement, and at the same time create opportunities at the professional front. For graduates, acquisition of generic skills enables them to enhance employment opportunities and prospects. This is presumed on the assumption that their core competencies in hard skills are adequately developed as well. 
In 2007, the Malaysian Ministry of Higher Education (MOHE, 2007) Tracer Study gave an overall result of $53.4 \%$ for graduates in Malaysia were employed, while $29.7 \%$ were not. In the same study (2007), Universiti Malaya graduates ranked highest with an employability rate of $97.0 \%$, followed by Universiti Teknologi Malaysia (84.0\%), Universiti Sains Malaysia (69.0\%), Universiti Putra Malaysia (67.0\%), Universiti Kebangsaan Malaysia (54.0\%), and at sixth position was Universiti Utara Malaysia (49.0\%) (Chan \& Norehan, 2007).

This study indicates the concern whether this scenario is applicable to all research universities, or only to specific universities. One of the issues of graduate unemployment is that the graduates are not employed according to their academic qualification. Assuming that they are qualified in their core discipline, the focus of this paper is on the generic skills and competencies of the graduates. Thus, this study is a micro study on the employability of social sciences graduates. Employability studies analyze students who have graduated and who have just entered the workforce. This study differs from previous studies that focused on employed graduates (Brown, Hesketh, \& Williams, 2003; Macianskiene, 2009; Ramli, Nawawi, \& Chun, MPP, 2010) because it investigates employers' perception on undergraduate trainees. Another difference is on the scope of the study, where in most cases such investigations would involve occupations and stakeholders in the central region of Malaysia; this study looked at the needs and perceptions outside the central region. The area is crucial because it has not been studied before, especially in the Malaysian context, yet it is expanding; hence, jobs and stakeholders are increasing in number. Satisfaction towards the generic skills of the graduates must be taken seriously because often the degree itself does not reflect generic/work competency and efficiency.

On the demand side, numerous studies have examined the private sector employer's perspective, but few studies have examined the public sector employer's perspective. Also, few studies have explored the generic skills gap that exists between what employer's perceive the desired skills prospective graduates should posses and what the prospective graduates actually possess. The objectives in this study are two-fold: i) to identify employers' perception of the ideal generic skills that graduate employees should possess, and 2) to elicit employers' perception of the lack of generic skills that prospective graduates (i.e. industrial trainees) currently possess. The authors recognized the need to elicit the employer's perspective to identify the generic skills that graduates should possess for the work place. Besides that, the extent to which the prospective graduates lack those generic skills required by employers will also be identified. The results will reveal the skills gap that will further provide information as to the role of the respective stakeholders and institutions in imparting the generic skills effectively.

\section{Literature Review}

\subsection{Theoretical Debate on Employability}

This section examines the contemporary consensus and conflict theory of employability of graduates (Brown et al. 2003) and attempts to seek integrate them by formulating a model of explanatory form together with the existing empirical literature.

First, Consensus Theory places emphasis on what social groups have in common, often relating to what the social norms or cultural shared beliefs (Brown et al. 2003). It is based on the belief that human capital injection by way of instilling generic skills at tertiary level will ensure employability of graduates and their eventual fast acceleration/leap frog in the corporate ladder. Consensus theory tends to blame the academia or university environment for not instilling sufficient skills through curriculum design and implementation through appropriate pedagogical methods. The theory is somewhat attuned to a normative utilitarian explanation which is rather simplistic. Perez et al. (2010) have referred to the challenges related to the multidimensional nature of the employability concept, especially the difficulty of disentangling the role of education and training systems from other factors in evaluating labour market outcomes.

Meanwhile, Conflict Theory emphasizes the fact that different groups, namely employer, academia, employees, have varying access to power and opportunities (Brown et al. 2003). In the capital-labour conflict there has been a continuous debate in terms of the employer's role in imparting generic skills and employees not acquiring adequate skills through training offered by employers. Meanwhile, there is the employer-academia conflict where the employers feel that the academia have not been providing adequate acquisition of generic skills to the graduates. The Conflict Theory argues for the employers to take responsibility in providing work place experience to the graduates and not directing the responsibilities to the universities alone.

The consensus theory and the conflict theory have their own limitations in view of the historical evolution of generic skills acquisition, where not only university environment provides avenue for such skill development but it also entails pre-university environment such as school, family, social, neighbourhood and workplace 
environment. There is now the need to examine the employers' perspective in terms of the skill gap and the various stakeholders to take responsibility in overcoming the gap.

\subsection{Past Studies}

The issue of acquisition of generic skills amongst graduates is often related to multiple factors such as the tertiary educational training, industrial experience, employer's role, and the graduates' attributes. Past studies on employability of graduates have placed great emphasis on the supply side efforts in generic skills development which includes the tertiary curriculum design and delivery mechanisms (Qi and Zhao, 2009; Mukthar et al. 2009).

Increasing globalization of professional jobs/careers has placed demands upon students and graduates to excel academically and also to enhance their generic skills. According to Fallows and Stevens (2000), there is a need for university wide initiative to build employability skills in particular generic skills into the higher education curriculum, in line with the Consensus Theory. They offer two key reasons: first, knowledge of academic subject is inadequate in current economic situation. Second, graduates need to gain generic skills that will enhance their employability. This demand has led universities to review and adapt their curriculum to infuse generic skills through varying means, some through direct intervention at curriculum level, while others through integrative mechanism. The focus on this review and infusion of generic skills has been at the undergraduate level.

Fallows and Stevens (2000) have identified generic skills as encompassing the following:

1) retrieval and handling information (i.e., classification and analysis)

2) communication and presentation (i.e., written and oral communication)

3) planning and problem solving (i.e., critical evaluation, practical and technical experience)

4) social development and interaction(i.e., interpersonal, responsibility, teamwork)

There were wide range of employability studies and importance of generic skills from the perspective of employers in the extant literature. A study on communication skills in Lithuanian enterprises identified the need for plurilingual competence which is also related to intercultural competence development (Macianskiene, 2009). Meanwhile Lobont (2009) asserts the importance of research skill in the engineering professional career and engineering applications. Santiago's (2009) study on workplace exposure of students for longer hours on a full-time basis are likely to receive better first-job level positions after they graduate. They found that sandwich program where a period of actual work exposure within a student's curriculum are likely to impact the first job experience of its graduates.

Li's (2011) study on Shenzhen tourism enterprises' perception on university graduates in terms of employable skills shows that these employers are dissatisfied with the personal characteristics of graduates in terms of work initiative, loyalty, responsibility, visionary skills and ability to work independently.

A review of generic skills amongst graduates in selected Asian countries was undertaken by Zaharim et al. (2009). They did a literature search (i.e., articles, journals, papers, and reports) on engineering employability skills in four countries in Asia (i.e., Malaysia, Japan, Singapore, and Hong Kong) and found that employers identified three important generic skills, namely communication skills, problem-solving and interpersonal skills.

There are several studies on generic skills in Malaysia that have emphasized on the perception of employers on graduates who are employed, and these studies primarily dealt with natural and applied science disciplines; and few studies have also been done in social sciences. Study by Ramli et al. (2010) on the perception of employers on the generic skills of physiotherapy graduates in Malaysia suggest the importance of thinking and research skills, discipline-based problem-solving skills, as well as information and professional skills. Study by Othman et al (2010) suggest that changes in the method of teaching (i.e. supply side) utilizing problem-based learning (PBL) can enhance the employability of graduates. For example they found that PBL utilized in applied mathematics can enhance employability skills of engineering graduates. A study by Zaharim et al. (2009) identified the perception and the expectation of employers on skills owned by engineering graduates in their work place. The finding indicates that the majority of those companies employing graduates have been satisfied with the knowledge and skills of the graduates they recruit. Employers' expectation and perception play an important role in determining the employability skills needed.

Another study by Husain et al. (2010) on engineering firms' found that graduates have information skills and technology skills that vary significantly, suggesting diverse acquisition of skills by students with similar disciplinary background. Thus, in line with the limitation of the Conflict Theory, we hypothesized that generic skills can be acquired from varying context such as family, friends, social circles, work places and even personal 
attributes matters.

As can be seen from numerous studies that have examined employers' perspective in the private sector but few studies have examined employer's perspective in the public sector. Also, few studies have explored the generic skills gap that exists between what employers perceive as the desired skills prospective graduates should posses and what they actually possess.

\section{Method}

\subsection{Participants and Study Area}

The study is about the perception of the employability of social science discipline undergraduate students undergoing industrial training (from here on referred to as prospective graduates) in public sector bodies from the perspective of the public sector employers. The importance of identifying the graduate's generic skills from the public sector employer's perspective is to enable various stakeholders and institutions to take responsibility and initiate reform measures in imparting the relevant and appropriate skills to the graduate students.

The participants for this research were employers selected based on where the social science industrial trainees from UKM (Universiti Kebangsaan Malaysia) attended, basically in the cities of Kuantan (east coast of Peninsular Malaysia) and Johor Bahru (south of Peninsular Malaysia). The rationale for choosing trainees from these two locations is to capture the employability experience as perceived by the employer outside the central region of development in Peninsular Malaysia. Marked differences were found between subject areas of trainee students, namely psychology, mass communication, language, development studies, sociology disciplines, and the diverse function and bodies of the public sector employers, namely local authorities such as Kuantan Municipality and District Land office to federal level district level offices such as welfare department and youth department. As such the assumption is that the student trainees are situated in appropriate or close-fit discipline areas in the respective public organizations. For example, the sociology student was attached to the welfare department, while the mass communication and linguistic double majors was attached to the broadcasting unit in RTM.

\subsection{Data Collection and Analysis}

In order to capture the perspective of the public sector employers on undergraduate trainees in their organization, a qualitative research design was utilized involving employers as key informant. Data were collected using key informant interview to elucidate the subjective experience of employers on undergraduate students undergoing training in their organization. Primary interview data were collected through a total of 16 key informant interviews of employers in the public sector who formed the main participants of the research. Eight key informants from the Kuantan area and another eight informants from the Johor Baharu area were selected. These interview data were then analyzed using content analysis and were later compared with extant literature to identify unique and contextual features.

\section{Results}

The results of the study indicate that five main categories of generic skills that employers perceived as essential must-haves for prospective graduates are as indicated in Figure 1. 


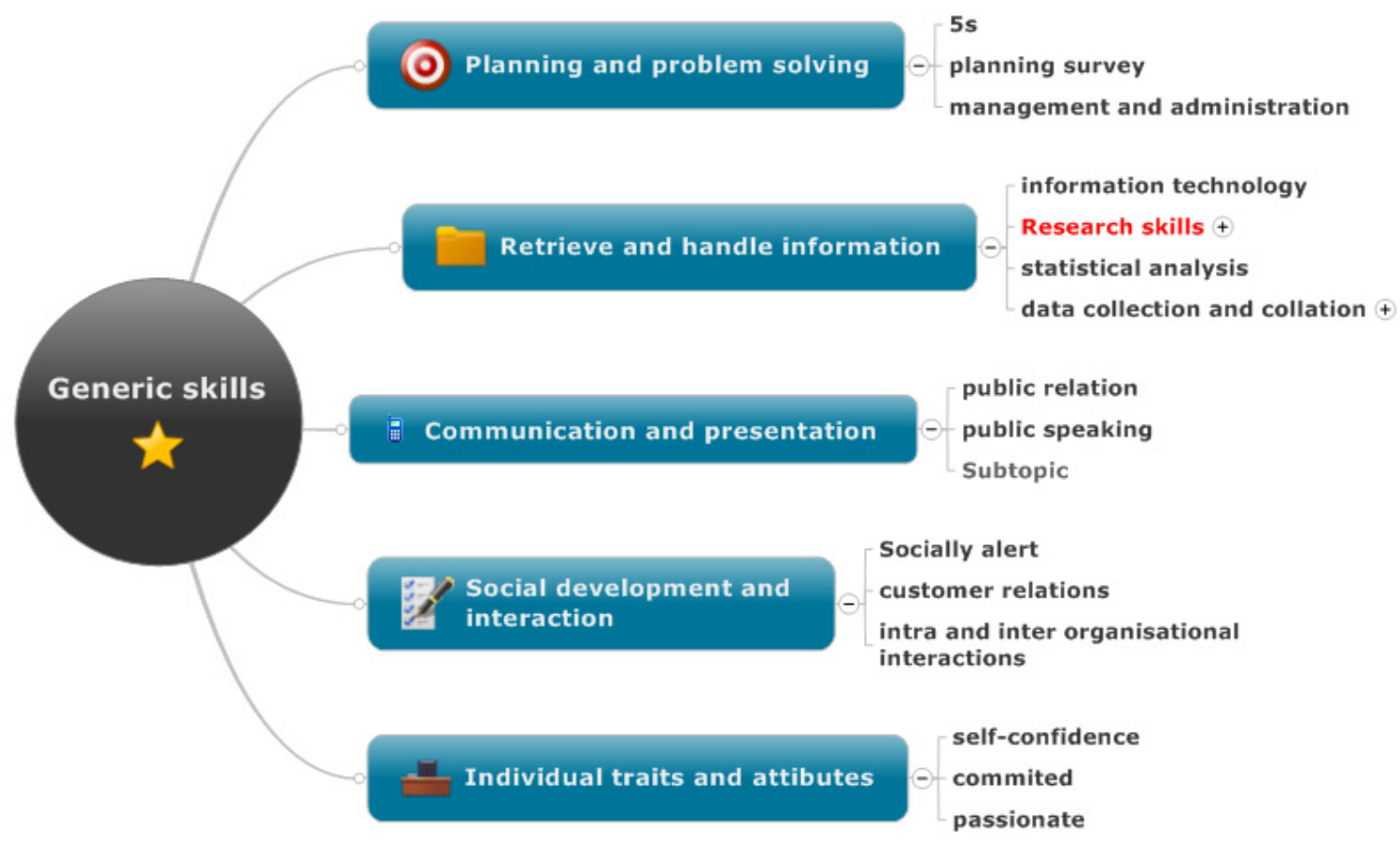

Figure 1. Generic skills from the public sector employers'

\subsection{Retrieve and Handle Information}

The majority of the employers regarded computer skills as critical to organizational needs. In addition to basic knowledge in the use of softwares such as Word, Excel, and Access, they recommend that graduates must have adequate knowledge on statistical packages such as SPSS and mapping and spatial tools like GIS (Mapinfo) and Auto CAD. Here the importance of information technology skills is highlighted particularly relevant to the public sector agencies.

Besides that, the employers expect graduates to have adequate research skills to undertake basic survey as well as to analyse the data collected to furnish factual information spontaneously to stakeholders. For example, user survey on recreational parks warrants quick results to aid in the design of projects and to facilitate decision-making processes. The public sector move towards outcome based service provision has meant that increasing use of evidence-based program measures requires sufficient research skill.

\subsection{Communication and Presentation Skills}

The employers have highlighted two major types of communication skills that graduates should possess namely, public relation skills and public speaking skills. The study reveals that public relation is crucial in the public sector when the clients come from varying stakeholder interests. The public relations that the employers referred to include service provision matters such as welfare services where the prospective employees need to relate with people with special needs, the aged citizens, as well as entertaining various complaints from the public. Possessing the skills means that the graduates have to be mentally and physically prepared with adequate verbal and nonverbal abilities to absorb and adapt to different groups and different situations, or encounters.

Meanwhile the public speaking skills are also equally crucial for the graduates to be recognized as apt officers. The skills entail mainly the persuasive and rhetoric abilities which are necessary when dealing with stakeholders, decision makers, counselors, and politicians. For example an employer from a youth department cited "..they must be able to jual air liur" (literally: sell saliva, a Malay figurative expression which means possessing oral persuasive skills). In another instance, the officer from the Planning and Development Department in a Local Authority perceives "graduates need to possess the ability to simplify abstract complex information for stakeholders, for example, by presenting the information in simplified graphic forms." They also need to acquire the skills of data presentation specifically with respect to "...elaborating in PowerPoint presentation."

Self-confidence is an underlying aspect towards effective public-speaking ability where it is a fundamental element that automatically could counter the problem of shyness, reticence, withdrawal, and non-inquisitiveness. Trainees who will soon be joining the work force should be able to convince stakeholders, hence, need to be conversant, possessing ability to simplify complex information for the stakeholders. 


\subsection{Planning and Problem Solving}

The employers perceive that trainees should be well versed in their planning and problem-solving skills. For example, they should be good in the $5 \mathrm{~S}$ (sort, set-in-order, shine, standardize, sustain) system. The $5 \mathrm{~S}$ system is a basic, fundamental, systematic approach for productivity, quality, and safety improvement in all types of business.

As graduates usually assume a position at the management or administration level, and hence, they should be a role model for their staff. The trainee should also be passionate and should enjoy working with welfare groups, helping others in need and always eager to learn new things. For example, a trainee was placed in the position of an officer; thus, "is required to attend a meeting; but he or she does not seem to know how to conduct the meeting, and ignorant of the protocols and pragmatics in a meeting" (from the perspective of Kuantan District Council officer).

In addition, trainees must be able to do planning survey, and develop concept plans if they intend to work in a management or administrative position. A simulation was carried to test the trainees' ability to assess the types of facilities and other requirements needed for physical planning, but they "did not exhibit these skills adequately" (from the perspective of Johor Bahru municipality officer).

\subsection{Social Development and Interaction}

In terms of social development and interaction, employers expect the trainees to be knowledgeable and able to express themselves confidently with clients from diverse communities and industrial backgrounds. They must be adaptable, multi-talented and resourceful. However, the trainees were not found to be socially alert beyond their disciplinary realm and they were not cognitively aware of current issues and the social and market dynamics. These concerns were expressed by a broadcasting officer from Radio-Television Malaysia (RTM).

Social interaction is important. For example, a public municipal employer voiced out his view as follows:

1) Lack of self-confidence in terms of giving opinions. Students appeared to have the knowledge, but were uncertain in expressing their opinions.

2) Unable to express opinions beyond their disciplinary realm. According to this officer, the trainees must possess the ability to interact with the organization and be alert of what is happening around them.

3) Not inquisitive especially as a new employee.

Usually, a generation gap exists between the senior and the junior staff; so if the trainee is not inquisitive, he or she is losing. Trainees must understand that graduates can climb up the ladder fast if they are inquisitive, open-minded, and less egoistic towards their seniors. The new staff must create a good rapport with the seniors once they step into the industry.

\subsection{Individual Traits or Attributes}

Aside from communication and speaking skills, graduates should also be committed to their work, overcome shyness or reticence, and willing to be self-reliant. They must take the initiative to learn, experiment, and execute tasks without depending on orders. For example, one officer from a Local Municipality phrased his opinions about the needs for the trainees to work with "minimal supervision," by adopting an attitude of "able to do work on their own." They need to improve their general knowledge by increasing their reading habits as there is a "lack of reading especially on general knowledge, and so on; not knowing the role of the Municipality Council, the number of State Assemblymen, etc." They must also be resourceful to "know who to communicate with, and what to communicate with in the Municipality Council."

Basically, the officer found the trainees who will be graduating soon need to be inquisitive for institutional knowledge of the locality. Another officer from the Local Drainage and Irrigation Department emphasized that the trainees should have public relation skills with a focus on having self-confidence to give opinions at various stages of their job-cycle. These individual traits are part of the requirements for effective generic skills because the nature of their work needs them to liaise with diverse agencies. In other words, the trainees must be aware of the reality of the job requirement and are able to adapt to their respective needs.

\section{Discussion}

Fallows and Stevens (2000) have identified four generic skills, namely retrieval and handling information; communication and presentation; planning and problem solving; social development and interaction. Meanwhile, Conflict Theory highlights the hypocrisy of the employers, and them being not responsible in working with the university to instill work experience skills. For example, through internship programs the employers can provide 
opportunities for work place experience. Besides that, employers can enhance the employee's limitation by providing training by way of gaining commitment of employees in undergoing training based on co-payment principle. Employers appear to capitalize on surplus graduate market situation by insisting university suppliers to provide readymade comprehensive skilled graduates with adequate experience for industrial employment.

On the other hand, Conflict Theory argues that consensus was impossible unless differences in power and wealth are recognized. Generic skills can be acquired in varying context (Crebert 2002). Crebert (2002) has identified generic skills; and the development of graduate attributes can be acquired in three contextual areas, namely: (1) University context: written communication, oral communication, teamwork, analysis, and critical evaluation; (2) Work placement context: oral communication, knowledge, written communication, practical and technical experience, and interpersonal skills; (3) Employment context: oral communication, written communication, teamwork, assuming responsibility and making decisions, and practical and technical experience/interpersonal skills. Besides the three contextual areas, personal attributes also play a part in employability (Learning and Teaching Support Network, 2004).

There are others who have differentiated generic skills in a narrow sense as comprising imparting such skills through the university programs and other skills (such as professional skills) acquired in employment environment. However since university programs are integrated with workplace experience, such narrow distinction has been avoided.

From the above findings there are some overlapping and resonating themes across several dimensions of social development, communicative aspect and personal attribute described earlier. The employers are basically looking for confident, inquisitive and outgoing employees who can not only stay engage with the staff in the organization but also with their clients and stakeholders as well. In fact graduates are expected to display these leadership qualities if they are to be employable and climb the corporate ladder.

Our findings in public sector employers' expectation on social science generic skills support most of what Zaharim et al.'s (2009) assertion about the employers' expectation in the engineering field in Asia where both communication skills and interpersonal skills are equally important, though in our study problem solving skill was not as important. However public sector employers tend to overemphasis planning surveys and procedural matters. Our findings also appear to resonate with some of the previous literature especially Lobont's (2009) need for research skill which is also increasingly being applicable in the public sector. Also Li's (2011) study on personal attributes lacking work initiative, and ability to work independently appears similar to our experience. However there are some culture specific problems in social interaction encounter in the Malaysian case where graduate trainees appear to have generational gap.

Most of the reservations employers had on prospective graduates can be partially addressed by wider workplace exposure as postulated by Santiago (2009) sandwich program. This is in line with Conflict Theory's assumption that employer too have to take responsibility in imparting some of the skills that are simply not available in other environments. The German education model provides a good example of industry working hand in hand with the university, where the industry itself is actively involved in formulating curriculum. Besides that, the university lecturers are attached with the industry and the industry players can switch to the university environment.

Employability skills have often fallen on acquisition of generic skills and development of graduate attributes. Since the continuum of employability skills is lifelong learning, the acquisition of such generic skills can start from the personal attributes of the individual graduates, to successive learning and socialization through family, community, schooling, university, and employment experiences. In fact Bridgstock (2009) argues that employability involves far more than possession of the generic skills attributes and acknowledges the importance of self-management and career building skills to lifelong career management and enhanced employability

\section{Conclusion}

The issue of generic skills amongst graduates is often related to multiple factors such as the tertiary educational training, industrial experience, employer's role, and the graduates' attributes. Past studies on employability of graduates have placed great emphasis on the supply-side efforts in generic skills development which includes the tertiary curriculum design and delivery mechanisms. This is consistent with the Consensus Theory of human capital development which postulates that instilling generic skills at tertiary level will ensure the employability of graduates and their subsequent rise in the corporate ladder. On the other hand, the Conflict Theory has raised doubts on the feasibility of the role played by tertiary education and questioned the responsibility of employers in providing training to prospective graduates, and in collaborating with universities in enhancing generic skills.

This study intended to explore the employers' expectations of the graduates based on their experiences with 
undergraduate industrial trainees from the social sciences discipline. The results of the study conclude that there is a mismatch between employers' expectations and the trainees' skills. This implies that measures to improve transferable skills are not the responsibility of the tertiary education system only, but the industry has to play the greater role to provide on-the-job training. Besides that, students should be encouraged to participate in multiple organizations experiences, develop passion for life-long learning, enhance their talents, cultivate reading habits and have a enquiry mind.

We can elucidate the varying levels of acquisition of generic skills at different contexts, namely university context, placement context, and employer context. This information is vital in coalescing strategies, policies, and programs at the university educational programs in an integrated manner, as well as in formulating strategic partnership with employers and policy makers, so that the burden of generic skills development is not the sole responsibility of university, but also of corporate organizations', the state and learners/graduates' responsibility as well. Future studies should thus examine not only social sciences undergraduates, but also post-graduates from various disciplines, either from the natural or social sciences.

Therefore, future studies should examine the extent to which employers impart transferable skills to trainees and also to be engaged in the development of tertiary curriculum as required under the Malaysian Qualifications Framework for stakeholder involvement.

\section{Acknowledgements}

The authors wish to acknowledge UKM (Universiti Kebangsaan Malaysia) for funding the research on Postgraduate Learning and Sustainable Employability: A Case Study of UKM. Strategic Action Research Grant (PTS) Code: PTS-2011-133 under the leadership of Associate Professor Dr Marlyna Maros and also to Research Grant UKM-DLP-2012-030 under the leadership of Associate Professor Dr Er Ah Choy.

\section{References}

Bridgstock, R. (2009). The graduate attributes we've overlooked: enhancing graduate employability through career management skills. Higher Education Research \& Development, 28(1), 31-44. http://dx.doi.org/10.1080/07294360802444347

Brown, P., Hesketh, A., \& Williams, S. (2003). Employability in a knowledge-driven economy. Journal of Education and Work, 16(2), 107-126. http://dx.doi.org/10.1080/13639080305562

Chan, L. Y., \& Abdullah, N. (2007). Produktiviti bagi sistem pengajian tinggi di Malaysia(In Malay), Productivity in higher education system in Malaysia(Translation). Kajian Malaysia, 25(2), 75-120.

Crebert, R. G. (2002). Institutional research into generic skills and graduate attributes: Constraints and dilemmas. Higher Educational Research \& Development, 21(1), 121-135.

Fallows, S., \& Stevens, C. (2000). Building employability skills into the higher education curriculum: A university-wide initiative. Education and Training, 42(2), 75-83. http://dx.doi.org/10.1108/00400910010331620

Husain, M. Y., Mokhtar, S. B., Ahmad, A. A., Mustapha, R., Husain, M. Y., Mokhtar, S. B., \& Mustapha, R. (2010). Importance of employability skills from employers' perspective. International Conference on Learner Diversity (ICELD). Univ Kebangsaan, Bangi, Malaysia, Oct 19-20. Proceedings of International Conference on Learner Diversity 2010. Procedia Social and Behavioral Sciences, 7, 430-438.

Li, W. L. (2011). An Empirical Study on Tourism Enterprises' Satisfaction with University Graduates-From the Perspective of Employable Skills. International Conference on Applied Social Science. Changsha, Peoples Republic of China, Mar 19-20, In Zhou, Q.Y. (Ed.), International Conference On Applied Social Science (vol. V, pp. 449-453).

Lobont, L., Lungu, A., \& Rotaru, M. I. (2009). Training for research in engineering study programmes. 5th Balkan Region Conference on Engineering and Business Education/2nd International Conference on Engineering and Business Education, Lucian Blaga Univ, Sibiu, Romania, Oct 15-17. In Oprean, C., Grunwald, N., \& Kifor, C.V. (Eds.), Conference Proceedings Balkan Regional Conference On Engineering And Business Education \& ICEBE (vol. I-II, pp.182-185).

Macianskiene, N. (2009). Plurilingual competence development as a prerequisite for employability. 3rd International Conference on Global Cooperation in Engineering Education - Innovative Technologies, Studies and Professional Development Kaunas Univ Technol, Kaunas, Lithuania, Oct 01-03. Global 
Cooperation in Engineering Education Innovative Technologies Studies and Professional Development- the Third International Conference Proceedings, 25-31.

Mukhtar, M., Yahya, Y., Abdullah, S., Hamdan, A. R., Jailani, N., \& Abdullah, Z. (2009). Employability and Service Science: Facing the Challenges via Curriculum Design and Restructuring. International Conference on Electrical Engineering and Informatics. Bangi, Malaysia, Aug 05-07. In IEEE (Eds.), International Conference On Electrical Engineering And Informatics (vol. 1-2, pp. 346-350). http://dx.doi.org/10.1109/ICEEI.2009.5254712

Othman, H., Buntat, Y., Sulaiman, A., Salleh, B. M., \& Herawan, T. (2010). Applied Mathematics cans Enhance Employability Skills Through PBL, International Conference On Mathematics Education Research 2010 ICMER 2010 Malacca, Malaysia, Dec 13-14. Procedia Social and Behavioral Sciences, 8, 332-337.

Perez, E. A., Garrouste, C., \& Kozovska, K. (2010). Employability: Challenges for Education and Training Systems. 1st International Conference on Reforming Education, Quality of Teaching and Technology-Enhanced Learning: Learning Technologies, Quality of Education, Educational Systems, Evaluation, Pedagogies. Athens, Greece, May 19-21. In Lytras, M. D., DePablos, P. O., Avison, D., Sipior, J., Jin, Q., Leal, W., Uden, L., ... Horner, D. (Eds.), Technology Enhanced Learning: Quality Of Teaching And Educational Reform (vol. 73, pp. 292-300). Book Series: Communications in Computer and Information Science.

Qi, D. H., \& Zhao, X. (2009). Research on critical employment circumstances when college graduates facing financial crisis. International Forum of Human Resource Strategy and Development Univ Jinan, Jinan, Peoples Republic of China, Oct 24-25. In Zhang, S. F., Zhang, H., \& Song, L. (Eds.), Human Resources Management in the Knowledge Economy Era (vol. I-II, pp. 729-731).

Ramli, A., Nawawi, R., \& Chun, M. P. P. (2010). Employees' perception of employability skills needed in todays workforce among physiotherapy graduates, International Conference on Learner Diversity 2010, Universiti Kebangsaan Malaysia, Bangi, Malaysia, Oct 19-20. Procedia Social and Behavioral Sciences, 7, 455-463.

Rao, M. S. (2010). Soft skills enhancing employability: Connecting campus with corporate. New Delhi: International Publishing House.

Santiago, A. (2009). Impact of Sandwich Course Design on First Job Experience. Asia-Pacific Education Researcher, 18(2), 205-217.

Zaharim, A., Yusoff, Y. M., Omar, M. Z., Mohamed, A., \& Muhamad, N. (2009). Engineering employability skills required by employers in Asia. 6th WSEAS International Conference On Engineering Education Rodos, Greece, Jul 22-24. In Dondon, P., Martin, O., Zaharim, A., Mladenov, V., Bojkovic, Z., \& Biolek, D. (Eds.), Proceedings of The 6th WSEAS International Conference On Engineering Education - Recent Advances in Engineering Education (pp. 195-201).

Zaharim, A., Yusoff, Y. M., Omar, M. Z., Mohamed, A., \& Muhamad, N. (2009). Employers' Perceptions and Expectation toward Engineering Graduates: A Study Case. 6th WSEAS International Conference on Engineering Education Rodos, Greece, Jul 22-24. In Dondon, P., Martin, O., Zaharim, A., Mladenov, V., Bojkovic, Z., \& Biolek, D. (Eds,). Proceedings of the 6th WSEAS International Conference On Engineering Education - Recent Advances in Engineering Education (pp. 23-29). 